\title{
Eksistensi Jasa Transportasi Konvensional Milik Masyarakat Lokal pada Era Revolusi Industri 4.0 di Kelurahan Ubud, Bali
}

Fransisco Situmorang1, Agnes Anggi Hasian Silaban², Ziyadatur Rohmi³, Ida Bagus Suryawan ${ }^{4}$

fransiscositumorang41@gmail.com¹ ${ }^{1}$, gnesanggihs@gmail.com² ${ }^{2}$, ziyadaturrohmi97@gmail.com³

idabagussuryawan.unud.ac.id 4

Program Studi S1 Destinasi Pariwisata, Fakultas Pariwisata,Universitas Udayana, Jl. Dr. R. Goris, Denpasar, Bali 80232 Indonesia

\begin{abstract}
The presence of online transportation services in Ubud Village is considered a threat to the existence of conventional transportation services. Far-reaching price differences trigger conflict. This study aims to analyze the existence of conventional transportation services in the Ubud Village in the era of the industrial revolution 4.0. This study uses qualitative and quantitative data with primary and secondary data sources. Data obtained through the study of literature, observation, interviews, documentation, and questionnaires. The techniques for determining informants and determining the samples used are purposive sampling and incidental sampling. This research uses descriptive-qualitative analysis techniques and the Importance of Performance Analysis. The results showed that conventional transportation services still existed in the era of industrial revolution 4.0 due to an organization formed under the auspices of the Desa Adat which prohibits the operation of online transportation services. This research is expected to be a reference for the Bali Government and the Regency of Gianyar Government in compiling a policy regulation governing tourism transportation services in the Ubud Village.
\end{abstract}

Keyword: Revolution 4.0, Existence, Transportation Service

\section{PENDAHULUAN}

Kelurahan Ubud sebagai sentra sekaligus ikon pariwisata budaya di Provinsi Bali dan Indonesia tampaknya mengalami perkembangan yang begitu pesat. Hal ini dapat dilihat dari transformasi Ubud dari desa kecil berbasis agraris menjadi magnet pariwisata Bali berkelas internasional yang berkontribusi terhadap 70\% kas daerah Kabupaten Gianyar (Pramudya dan Arida, 2016). Ubud memiliki citra sebagai global village atau desa global yang dipenuhi oleh wisatawan mancanegara, domestik dan masyarakat lokal. Desa global ini terbentuk akibat perkembangan teknologi yang mampu mempersempit jarak dan menghubungkan masyarakat internasional layaknya masyarakat di sebuah desa kecil (Narrotama :2018).

Laju perkembangan pariwisata Ubud yang kian melejit berdampak terhadap peningkatan laju pertumbuhan ekonomi daerah dan kesejahteraan masyarakat lokal. Pembangunan sejumlah prasarana dan sarana yang acapkali mengabaikan daya tampung terus dilakukan dengan alasan untuk memenuhi kebutuhan wisatawan. Namun, hal tersebut nyatanya menjadi boomerang yang terus menggerus citra pariwisata berbasis budaya di daerah ini. Kemacetan lalu lintas yang terjadi di Ubud nampaknya menjadi sebuah konsekuensi logis atas ketidaksiapan Ubud dalam mengimbangi pesatnya perkembangan pariwisata sekaligus sebagai simbol kegagalan pemerintah dalam menata ruang publik dan kawasan pariwisata (Nurjaya : 2013 ; Pramudya dan Arida : 2016).

Isu kemacetan ini kemudian kerap dijadikan sebagai kambing hitam dalam persaingan jasa transportasi di Ubud. Pihak penyedia jasa transportasi konvensional menuding bahwa kehadiran jasa transportasi online menjadi salah satu penyebab kemacetan karena mereka menambah volume kendaraan dan parkir sembarangan. Hal ini kemudian memicu timbulnya konflik manifest antar penyedia jasa transportasi konvensional dan online. Konflik ini ditandai dengan adanya aksi demo penolakan dan pelarangan terhadap jasa transportasi online untuk mengangkut penumpang dari dalam Kawasan Ubud. Jasa transportasi online hanya diperbolehkan untuk drop off wisatawan saja (Pramudya dan Arida : 2016). Kasus serupa tampaknya tidak hanya terjadi di Ubud saja tetapi juga di daerah lain, seperti Aceh, Medan, Malang, Bogor, bahkan di sejumlah negara maju pada benua Eropa (Syafrino : 2017 ; Azizah dan Adawia : 2018 ; Adha : 2018 ; Angraini : 2018 ; Ramadhanu dan Supriono : 2018 ; Riswanda : 2019).

Kehadiran jasa transportasi online di Ubud maupun sejumlah daerah di Indonesia juga dianggap sebagai ancaman terhadap eksistensi jasa transportasi konvensional. Pengemudi lokal 
menganggap bahwa ketersediaan jasa dan kualitas pelayanan mereka sejauh ini masih baikbaik saja dan minim komplain dari wisatawan. Di sisi lain, kehadiran jasa transportasi online dianggap wisatawan mampu memberikan kemudahan dalam proses pemesanan dan sistem pembayaran, harga yang lebih transparan dan terjangkau, terdapat sistem penilaian atau rating serta memberikan rasa aman bagi mereka (Sumiati : 2017 ; Syafrino : 2017 ; Azizah dan Adawia : 2018 ; Adha : 2018 ; Angraini : 2018 ; Ramadhanu dan Supriono : 2018 ; Riswanda : 2019).

Hal ini didukung pula bahwa dewasa ini, dunia global telah memasuki era revolusi industri 4.0 yang menuntut adanya kecepatan fleksibilitas produksi dan peningkatan layanan kepada konsumen (Prasetyo dan Sutopo : 2018). Era revolusi industri 4.0 ini telah mentransformasi berbagai sektor menjadi lebih praktis dan kompleks melalui pemanfaatan teknologi yang terotomatisasi dan terdigitalisasi (Meranti dan Irwansyah : 2018). Sehingga akan terjadi disrupsi dalam berbagai aktivitas manusia, tidak hanya pada bidang teknologi, tetapi juga ekonomi, sosial dan politik (Prasetyo dan Trisyanti : 2018). Munculnya layanan jasa transportasi online merupakan hasil disrupsi pada aspek ekonomi, termasuk di dalamnya sektor pariwisata.

Sehingga, penelitian ini bertujuan untuk menganalisis tingkat permintaan dan penawaran serta menganalisis eksistensi jasa transportasi konvensional yang dikelola oleh masyarakat lokal di Kelurahan Ubud Bali pada era revolusi 4.0 saat ini. Adapun manfaat yang diharapkan melalui penelitian ini terbagi menjadi dua, yaitu manfaat akademis dan praktis. Secara akademis, hasil penelitian ini diharapkan mampu memberikan kontribusi berupa sumbangsih hasil pemikiran untuk memperkaya khazanah keilmuan pariwisata yang masih memiliki banyak kekosongan. Penelitian ini secara praktis diharapkan dapat dijadikan sebagai acuan bagi stakeholders pariwisata, khususnya Pemerintah Daerah Provinsi Bali dan Kabupaten Gianyar dalam merumuskan regulasi kebijakan mengenai sistem layanan transportasi di Kelurahan Ubud. Hal ini juga diharapkan agar para penyedia jasa transportasi online mengetahui bagaimana kondisi yang sebenarnya di Kelurahan Ubud Bali.

\section{TINJAUAN PUSTAKA}

Penelitian pertama berjudul "Transportasi Online VS Transportasi Tradisional Non Online Persaingan Tidak Sehat Aspek Pemanfaatan Aplikasi oleh Penyelenggara Online” yang dilakukan oleh Pribadiono (2016). Hasil penelitian menunjukkan bahwa tidak terdapat persaingan tidak sehat oleh transportasi online di Indonesia. Persaingan antara jasa transportasi online dan non-online lebih mengarah pada aspek efisiensi dengan pemanfaatan teknologi informasi dalam meningkatkan persaingan bisnis. Tinjauan terhadap penelitan bertujuan untuk mengetahui aspek hukum dalam praktik persaingan antara layanan transportasi konvensional dan online sesuai dengan topik penelitian yang diangkat saat ini.

Tinjauan penelitian selanjutnya berjudul "Dinamika Persaingan Usaha Masyarakat Lokal di Daerah Tujuan Wisata (Studi Komparasi pada Padangtegal Kaja Transport dan Taksi Aplikasi di Desa Padangtegal, Kecamatan Ubud, Bali" oleh Sumiati (2017). Pada penelitian ini dijelaskan bahwa kehadiran layanan transportasi online di Desa Padangtegal Ubud Bali menjadi ancaman terhadap eksistensi jasa transportasi konvensional karena memiliki keunggulan dalam hal sistem pemesanan yang praktis, kemudahan dalam pembayaran, harga yang lebih murah dan transparan. Tinjauan atas penelitian ketiga dapat dikatakan sebagai acuan dalam penelitian saat ini karena memiliki lokus dan fokus penelitian yang hampir sama.

Tinjauan selanjutnya adalah penelitian yang dilakukan oleh Riswanda (2019) dengan judul "Dampak Keberadaan Transportasi Online Terhadap Pendapatan Transportasi Konvensional (Studi Kasus Penarik Becak di Banda Aceh)". Hasil penelitian menunjukkan bahwa kehadiran transportasi online di Kota Banda Aceh sangat berpengaruh terhadap tingkat pendapatan penarik becak dan penurunan jumlah pelanggan. Tinjauan atas penelitian ini bertujuan untuk mengidentifikasi permasalahan sejenis di daerah lain dengan fokus yang berbeda dengan penelitian saat ini.

Pada penelitian ini, digunakan empat konsep untuk menganalisis data yang diperoleh. Adapun konsep tersebut, yaitu Eksistensi, Jasa, Permintaan dan Penawaran Jasa Transportasi, Revolusi Industri 4.0.

\section{Konsep Jasa}

Kotler (1993) mendefinisikan jasa sebagai sebagai segala kegiatan atau manfaat yang oleh suatu pihak ditawarkan ke pihak lainnya yang pada dasarnya tidak memiliki wujud dan tidak menghasilkan kepemilikan atas sesuatu (dalam Sari : 2003). Tjiptono (1996) menyebutkan bahwa jasa merupakan aktivitas, manfaat, atau kepuasan yang ditawarkan untuk dijual. Hal yang sangat patut diperhatikan dalam suatu jasa adalah kualitas pelayanan, yang terdiri dari lima dimensi, yaitu reliability, tangibles, responsiveness, assurance dan empathy (dalam Idrus : 2018). 


\section{Eksistensi}

Konsep eksistensi memiliki beberapa pengertian, yakni (1) Eksistensi adalah apa yang ada; (2) Eksistensi adalah apa yang memiliki aktualitas; dan (3) Eksistensi adalah segala sesuatu yang dialami dan menekankan bahwa sesuatu itu ada. Penekanan dalam konsep ini ialah sesuatu yang ada, dimana fakta merupakan satu-satunya faktor yang membedakan setiap hal yang ada dari tiada (Hadi : 2015 ; Majid : 2015 ; Retnowati : 2013). Menurut Abidin (2008) eksistensi tidak bersifat kaku dan terhenti, melainkan lentur atau kenyal dan akan mengalami perkembangan atau sebaliknya kemunduran, tergantung pada kemampuan dalam mengaktualisasikan potensi-potensinya (dalam Norhidayah : 2014).

\section{Permintaan dan Penawaran Jasa Transportasi \\ Steenbrink (1974) mendefinisikan} transportasi sebagai perpindahan orang atau barang dengan menggunakan alat atau kendaraan dari dan ke tempat-tempat yang terpisah secara geografis (dalam Sumiati, 2013). Permintaan atas jasa transportasi disebut sebagai permintaan turunan (derived demand) yang sangat bergantung pada permintaan terhadap produk-produk yang akan diangkut. Permintaan jasa transportasi menurut Setijowarno dan Frazilia (2001) pada dasarnya merupakan permintaan turunan dari: (1) Kebutuhan seseorang untuk berjalan dari suatu lokasi ke lokasi lainnya untuk melakukan suatu kegiatan; (2) Permintaan akan angkutan umum tertentu agar tersedia di tempat yang diinginkan.

Penawaran dalam transportasi akan dianggap cukup apabila permintaan kebutuhan terpenuhi tanpa adanya pengaruh dalam tarif perjalanan baik dari pihak penyedia transportasi maupun pembeli. Realitasnya, transportasi dalam kehidupan sehari-hari kerap ditawarkan pada tingkat harga tertentu sehingga bagaimanapun juga penawaran sangat dipengaruhi oleh harga yang terlibat. Penawaran jasa transportasi meliputi tingkat pelayanan dan harga yang dikenakan. Kenaikan harga dalam penawaran jasa transportasi juga mengakibatkan peningkatan jumlah yang dihasilkan dan ditawarkan untuk dijual (Andriyansah : 2015 dan Siwu : 2018).

\section{Revolusi Industri 4.0}

Konsep revolusi industri 4.0 mengacu pada pemanfaatan teknologi digital dalam menghadapi perubahan pasar yang begitu pesat, menawarkan lebih banyak produk yang bersifat personal, dan meningkatkan efisiensi opersional (Maltais, 2017). Industri 4.0 merupakan transformasi kompeherensif dari keseluruhan aspek produksi di industri melalui penggabungan teknologi digital dan internet dengan teknologi konvensional (Merkel : 2014 dalam Prasetyo dan Sutopo : 2018). Revolusi industri 4.0 juga dikatakan sebagai era disrupsi teknologi dan revolusi digital. Dikatakan sebagai era disrupsi teknologi karena melakukan otomatisasi dan konektivitas di sebuah bidang akan membuat sebuah pergerakan dunia industri dan persaingan kerja menjadi tidak linear. Industri 4.0 disebut sebagai revolusi digital karena terjadinya poliferasi komputer dan otomatisasi pencatatan di semua bidang (Yahya, 2018).

\section{METODE PENELITIAN}

Penelitian ini dilakukan di Kelurahan Ubud, Kabupaten Gianyar, Bali pada dua termin, yaitu penelitian pertama tanggal 20 Oktober - 07 November 2018 dan penelitian kedua pada tanggal 08 - 15 November 2019. Penelitian ini menggunakan metode kualitatif dan kuantitatif (mix method) untuk mempersatukan kedua jenis data menjadi database yang lebih besar yang dapat digunakan secara berdampingan untuk memperkuat satu sama lain (Cresswell dan Clark : 2007 dalam Cressweel : 2012). Penelitian ini menggunakan strategi ekploratoris sekuensial yang mengumpulkan dan menganalisis data kualitatif pada tahap pertama yang kemudian diikuti dengan pengumpulan dan analisis kuantitatif berdasarkan pada hasil-hasil pertama (Cresswell : 2012).

Sumber data dalam penelitian ini terbagi menjadi dua, yaitu data primer (Veal : 2006) dan data sekunder (Walliman : 2006). Data dalam penelitian ini diperoleh melalui studi kepustakaan (Bungin: 2007), observasi (Creswell : 2012), wawancara (Moleong : 2014), kuesioner (Bungin : 2005) dan dokumentasi (Bungin : 2007). Penentuan informan dalam penelitian ini menggunakan purposive sampling (Prastowo : 2016) dengan jumlah informan sebanyak 22 orang yang terdiri dari 5 wisatawan, 2 akademisi dan 15 pengemudi layanan transportasi konvensional. Sementara itu, teknik pengambilan sampel dalam penelitian ini adalah incidental sampling (Bungin : 2005). Teknik analisis data dalam penelitian ini dibagi menjadi dua, yaitu analisis dekriptif kualitatif dan analisis Importance Peform Analysis.

Teknik analisis data deskriptif kualitatif menggambarkan suatu fenomena, kemudian mengaitkannya dengan fenomena lain melalui interpretasi untuk dideskripsikan dalam satu kualitas yang mendekati kenyataan (Muhadjir : 1996). Adapun tahapan analisis deksriptif kualitatif menurut Miles dan Huberman (1992) ada empat, yaitu pengumpulan data, reduksi 
data, penyajian data dan penarikan kesimpulan (dalam Idrus : 2009). Teknik analisis Importance Performan Analysis yang digunakan untuk mengukur tingkat kepuasan wisatawan terhadap harga dan kualitas pelayanan yang diberikan oleh penyedia jasa tranportasi konvensional. (Supratno : 2011). Dalam penelitian ini dilakukan perhitungan berdasarkan tingkat kesesuaian harapan dan kenyataan pada harga dan kualitas pelayanan jasa transportasi konvensional yang diterima di Kelurahan Ubud.

\section{HASIL DAN PEMBAHASAN}

Pesatnya perkembangan pariwisata di Kelurahan Ubud ditandai dengan pembangunan sejumlah fasilitas pariwisata yang tidak pernah absen dilakukan dan jumlah kunjungan wisatawan yang cenderung meningkat setiap tahun. Pada tahun 2018, jumlah kunjungan wisman ke Kabupaten Gianyar melampaui target yang telah ditetapkan, yaitu 2,75 juta kunjungan dari 2,6 juta kunjungan wisman yang ditargetkan (bali.antaranews.com: 2019; bali-travelnews.com : 2019). Pencapaian ini sangat dipengaruhi oleh sejumlah destinasi wisata yang berhasil menarik minat wisatawan, utamanya yang berada di Kelurahan Ubud sebagai sentral aktivitas sekaligus ikon kepariwisatan Kabupaten Gianyar, seperti Monkey Forest (balipost.com : 2018).

Untuk menyelaraskan pertumbuhan kunjungan wisatawan mancanegara tersebut tentunya dibutuhkan sejumlah fasilitas pariwisata yang memadai, seperti layanan jasa transportasi. Namun, sampai saat ini Kelurahan Ubud maupun Pemerintah Daerah Provinsi Bali dan Kabupaten Gianyar masih belum mampu menyelesaikan polemik antara layanan jasa transportasi konvensional milik masyarakat lokal dengan kehadiran layanan jasa transportasi online. Masyarakat menganggap bahwa kehadiran transportasi online menjadi ancaman bagi mereka sementara wisatawan berpendapat bahwa hal tersebut lah yang justru mampu memenuhi kebutuhan mereka sesuai dinamika perkembangan zaman.

\subsection{Permintaan}

Berikut akan dijelaskan mengenai karakteristik wisatawan yang memakai jasa transportasi konvensional di Kelurahan Ubud berdasarkan kuesioner yang telah disebarkan kepada wisatawan:

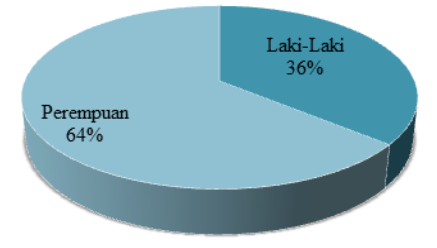

Diagram 4.1 Karakteristik Wisatawan Berdasarkan Jenis Kelamin

Berdasarkan diagram 4.1 dapat dilihat bahwa pengguna jasa transportasi konvensional di Kelurahan Ubud didominasi oleh wisatawan berjenis kelamin perempuan sebanyak 64\% sementara wisatawan berjenis kelamin laki-laki sebesar 36\%. Adapun pengguna layanan jasa transportasi konvensional menurut usia, seperti pada tabel 4.1, secara berturut-turut adalah sebagai berikut wisatawan dengan rentang usia 23-28 tahun (51\%), 29-34 tahun (19\%) dan >40 tahun (19\%). Hal ini menunjukkan bahwa wisatawan milennial merupakan pangsa pasar terbesar bagi penyedia jasa transportasi di Kelurahan Ubud.

Tabel 4.1 Karakteristik Wisatawan Berdasarkan Usia

\begin{tabular}{|c|c|c|c|}
\hline $\mathrm{N}_{0}$ & Usia & Jumlah Wisataw an & Persentase (\%) \\
\hline 1 & $17-22$ tahun & 2 & $4 \%$ \\
\hline 2 & $23-28$ tahun & 24 & $51 \%$ \\
\hline 3 & $29-34$ tahun & 9 & $19 \%$ \\
\hline 4 & $35-40$ tahun & 3 & $7 \%$ \\
\hline 5 & $>40$ tahun & 9 & $19 \%$ \\
\hline & Total & 47 & $100 \%$ \\
\hline
\end{tabular}

Sumber : Hasil Penelitian (2019)

Menurut negara asal, wisatawan Amerika Serikat menempati posisi sebagai pengguna layanan transportasi konvensional terbanyak dengan presentase 15\%, disusul oleh wisatawan domestik, wisatawan asal Inggris dan Perancis dengan presentase 13\% (Tabel 4.2). Adapun lokasi awal wisatawan dalam penggunaan layanan jasa transportasi konvensional seperti pada tabel 4.3, sebesar $76 \%$ berasal dari dalam kawasan Kelurahan Ubud. Dengan kata lain, 24\% wisatawan yang berada di Kelurahan Ubud tidak menggunakan jasa transportasi milik masyarakat lokal. Wisatawan ini umumnya berasal dari Denpasar, Kuta, Nusa Dua, Sanur, Canggu, Seminyak dan sebagainya yang memakai jasa transportasi dari luar Kelurahan Ubud untuk drop off. 
Tabel 4.2 Karakteristik Wisatawan Berdasarkan Negara Asal

\begin{tabular}{|c|c|c|c|}
\hline No & A sal Negara & $\begin{array}{c}\text { Jumlah } \\
\text { Wisataw an }\end{array}$ & $\begin{array}{c}\text { Persentase } \\
(\%)\end{array}$ \\
\hline 1 & Afrika Selatan & 1 & $2 \%$ \\
\hline 2 & Amerika Serikat & 7 & $15 \%$ \\
\hline 3 & Australia & 2 & $4 \%$ \\
\hline 4 & Belanda & 2 & $4 \%$ \\
\hline 5 & Filipina & 1 & $2 \%$ \\
\hline 6 & Finlandia & 2 & $4 \%$ \\
\hline 7 & Indonesia & 6 & $13 \%$ \\
\hline 8 & Inggris & 6 & $13 \%$ \\
\hline 9 & Jepang & 1 & $2 \%$ \\
\hline 10 & Jerman & 3 & $6 \%$ \\
\hline 11 & Malaysia & 1 & $2 \%$ \\
\hline 12 & Myanmar & 1 & $2 \%$ \\
\hline 13 & Perancis & 6 & $13 \%$ \\
\hline 14 & Republik Ceko & 1 & $2 \%$ \\
\hline 15 & Romania & 1 & $2 \%$ \\
\hline 16 & Selandia Baru & 3 & $6 \%$ \\
\hline 17 & Spanyol & 1 & $2 \%$ \\
\hline 18 & Switzerland & 2 & $4 \%$ \\
\hline & Total & $\mathbf{4 7}$ & $\mathbf{1 0 0} \%$ \\
\hline
\end{tabular}

Sumber : Hasil Penelitian (2019)

Tabel 4.3 Titik Awal Wisatawan dalam Penggunaan Jasa Transportasi Konvensional

\begin{tabular}{|c|c|c|c|}
\hline$N_{0}$ & $\begin{array}{c}\text { Daerah am al penggunaan jasa } \\
\text { transportasi }\end{array}$ & Jumlah Wisataw an & $\begin{array}{c}\text { Persentase } \\
(\%)\end{array}$ \\
\hline 1 & Sekitar Kelurahan Ubud & 36 & $76 \%$ \\
\hline 2 & Dari luar Kelurahan Ubud & 11 & $26 \%$ \\
\hline \multicolumn{2}{|c|}{ Total } & 47 & $100 \%$ \\
\hline
\end{tabular}

Sumber : Hasil Penelitian (2019)

Permintaan atas layanan jasa transportasi konvensional berdasarkan lama penggunaannya cenderung cukup singkat karena faktor jarak yang hendak dituju. Dapat dilihat pada tabel 4.4 bahwa wisatawan paling banyak menggunakan layanan transportasi ini selama 0-1 jam (32\%), 1-4 jam (30\%), 4-8\% (13\%), 8-12 jam (10\%), 12 - 24 jam (15\%) dan tidak ada yang lebih dari 24 jam. Sehingga, harga yang dibayarkan pun didominasi pada kisaran Rp 0-100.000,00 (38\%) yang disusul pada rentang harga $\mathrm{Rp} 101.000,00-250.000,00$ (17\%), Rp 251.000,00-500.000,00 (17\%), Rp $501.000,00-1.000 .000,00$ (21\%) dan > Rp $1.000 .000,00(7 \%)$.

Tabel 4.4 Lama Penggunaan Jasa Transportasi Konvensional

\begin{tabular}{|c|c|c|c|}
\hline No & Lama Penggunaan & Jumlah & Per sentase (\%) \\
\hline 1 & $0-1$ jam & 15 & $32 \%$ \\
\hline 2 & $1-4$ jam & 14 & $30 \%$ \\
\hline 3 & $4-8 \mathrm{jam}$ & 6 & $13 \%$ \\
\hline 4 & $8-12 \mathrm{jam}$ & 5 & $10 \%$ \\
\hline 5 & $12-24 \mathrm{jam}$ & 7 & $15 \%$ \\
\hline 6 & $>24 \mathrm{jam}$ & 0 & $0 \%$ \\
\hline \multicolumn{2}{|c|}{ Total } & 47 & $100 \%$ \\
\hline
\end{tabular}

Sumber : Hasil Penelitian (2019)

Tabel 4.5 Harga yang Dibayar Wisatawan terhadap Layanan Jasa Transportasi

Konvensional

\begin{tabular}{|c|c|c|c|}
\hline $\mathrm{N}_{\mathbf{0}}$ & Rentang Harga & Jumlah & Persentase (\%) \\
\hline 1 & $\operatorname{Rp} 0-\operatorname{Rp} 100.000,00$ & 18 & $38 \%$ \\
\hline 2 & $\operatorname{Rp} 101.000,00-\operatorname{Rp} 250.000,00$ & 8 & $17 \%$ \\
\hline 3 & $\operatorname{Rp} 251.000,00-\operatorname{Rp} 500.000,00$ & 8 & $17 \%$ \\
\hline 4 & $\operatorname{Rp} 501.000,00-\operatorname{Rp} 1.000 .000,00$ & 10 & $21 \%$ \\
\hline 5 & $>\operatorname{Rp} 1.000 .000,00$ & 3 & $7 \%$ \\
\hline \multicolumn{2}{|c|}{ Total } & 47 & $100 \%$ \\
\hline
\end{tabular}

Sumber : Hasil Penelitian (2019)

Berdasarkan kelima tabel yang disajikan, dapat dilihat bahwa tingkat permintaan terhadap layanan jasa transportasi konvensional di Kelurahan Ubud sangat dipengaruhi oleh tiga faktor, yaitu harga, jarak tempuh dan lama perjalanan. Sementara itu, permintaan tertinggi biasanya terjadi di pagi hari sekitar pukul 10.00 pagi, sore hari dan malam hari setelah setelah selesai pertujukan tari di Balai Banjar.

Adapun permintaan akan layanan transportasi konvensional di Kelurahan Ubud tidak dipengaruhi oleh harinya karena hampir setiap hari sama. Artinya, hari libur atau weekend seperti hari Sabtu dan Minggu tidak begitu berpengaruh terhadap jumlah kunjungan dan tingkat permintaanlayanan transportasi konvensional di Ubud. Berdasarkan hasil observasi dan wawancara, Kelurahan Ubud selalu ramai setiap hari, baik hari senin maupun sabtu sama saja. Hanya saja, untuk bulan, tingkat permintaan tertinggi berada pada bulan Juni, Juli dan Agustus yang merupakan high season.

Permintaan akan layanan jasa transportasi juga disesuaikan dengan kebutuhan wisatawan, misalnya bagi mereka yang ingin melakukan perjalanan ke daerah di luar Kelurahan Ubud maka para pengemudi lokal siap melayani. Berdasarkan hasil pengamatan di lapangan, tingkat kunjungan wisatawan memang di dominasi oleh wisatawan milenial yang berasal dari luar negeri (wisatawan mancangera). Aktivitas wisatawan di Kelurahan Ubud biasanya dilakukan dengan mengunjungi sejumlah daya tarik wisata budaya yang berdekatan dengan berjalan kaki, seperti dari Museum Puri Lukisan Ubud ke Puri Agung Ubud. Para wisatawan ini bisanya hanya memakai jasa transportasi konvensional untuk kembali ke penginapan atau menuju daya tarik wisata lain di luar Kelurahan Ubud.

\subsection{Penawaran}

Para pengemudi transportasi konvensional di Kelurahan Ubud menawarkan jasa mereka kepada para wisatawan dengan lima cara. Pertama, mereka menawarkan jasa secara 
langsung di sepanjang pinggir jalan kepada wisatawan yang sedang melintas. Kedua, pengemudi menawarkan layanan jasa transportasi melalui loket khusus yang dikelola oleh organisasi milik desa adat secara bergantian. Ketiga, pengemudi bekerjasama dengan beberapa pihak akomodasi maupun orang yang bekerja di dalamnya untuk turut memberikan rekomendasi bagi wisatawan yang membutuhkan layanan jasa tranportasi. Keempat, beberapa pengemudi memanfaatkan media sosial pribadi mereka atau situs tertentu, seperti tripadvisor untuk menawarkan layanan jasa transportasi. Dan kelima, para pengemudi tetap menjalin komunikasi (keep in touch) dengan sejumlah wisatawan agar turut memberikan rekomendasi bagi kerabat mereka yang hendak berlibur ke Ubud maupun Bali. Berikut adalah beberapa penawaran layanan jasa transportasi di Kelurahan Ubud yang diterima oleh wisatawan berdasarkan hasil kuesioner.

Tabel 4.6 Sumber Informasi Wisatawan terhadap Penggunaan Layanan Transportasi Konvensional

\begin{tabular}{|c|c|c|c|}
\hline No & $\begin{array}{c}\text { Sumber informasi tentang layanan } \\
\text { jasa transportasi yang digunakan }\end{array}$ & Jumlah & Persentase (\%) \\
\hline 1 & $\begin{array}{c}\text { Perusahaan penyedia jasa transportasi } \\
\text { menawarkan secara lang sung }\end{array}$ & 25 & $55 \%$ \\
\hline 2 & Teman & 6 & $13 \%$ \\
\hline 3 & Keluarga & 1 & $2 \%$ \\
\hline 4 & Rekan kerja & 1 & $2 \%$ \\
\hline 5 & Media sosial & 3 & $6 \%$ \\
\hline 6 & Website & 0 & $0 \%$ \\
\hline 7 & Lainnya (Pihak Hotel) & 10 & $21 \%$ \\
\hline \multicolumn{2}{|c|}{ Total } & 47 & $100 \%$ \\
\hline
\end{tabular}

Sumber : Hasil Penelitian (2019)

Berdasarkan tabel 4.6, wisatawan sebesar $55 \%$ mengetahui informasi mengenai layanan jasa transportasi konvensional melalui penawaran secara langsung yang dilakukan oleh pengemudi. Kemudian disusul melalui informasi dari teman (13\%), keluarga (1\%), rekan kerja (1\%), media sosial (3\%), dan dari pihak hotel (21\%).Sedangkan untuk mekanisme pemesanan yang dilakukan oleh wisatawan dapat dilihat pada tabel 4.7.

Tabel 4.7 Mekanisme Pemesanan Jasa

Transportasi Konvensional

\begin{tabular}{|c|c|c|c|}
\hline No & Mekanisme Pemesanan & Jumlah & Per sentase (\%) \\
\hline 1 & $\begin{array}{c}\text { Perusahaan penyedia jasa transportasi } \\
\text { menawwarkan secara lang sung }\end{array}$ & 35 & $75 \%$ \\
\hline 2 & $\begin{array}{c}\text { Pemesanan melalui sistem re servasi } \\
\text { konvensional }\end{array}$ & 6 & $12.5 \%$ \\
\hline 3 & $\begin{array}{c}\text { Pemesanan melalui sistem re servasi } \\
\text { online }\end{array}$ & 6 & $12.5 \%$ \\
\hline \multicolumn{2}{|c|}{ Total } & 47 & $100 \%$ \\
\hline
\end{tabular}

Sumber : Hasil Penelitian (2019)

Berdasarkan tabel 4.7, sebesar 75\% wisatawan melakukan pemesanan berdasarkan penawaran secara langsung oleh para pengemudi lokal yang disusul dengan pemesanan melalui sistem reservasi secara konvensional, baik yang melalui loket maupun pihak hotel $(12,5 \%)$ dan sistem reservasi online melalui media sosial $(12,5)$. Adapun sistem pembayaran yang digunakan oleh wisatawan seperti pada tabel 4.8 adalah secara tunai (48\%), debit (6\%), dan kredit (2\%).

Tabel 4.8 Mekanisme Pemesanan Jasa Transportasi Konvensional

\begin{tabular}{|c|c|c|c|}
\hline No & Sistem Pembayaran & Jumlah & Persentase (\%) \\
\hline 1 & Tunai & 43 & $92 \%$ \\
\hline 2 & Debit & 3 & $6 \%$ \\
\hline 3 & Kredit & 1 & $2 \%$ \\
\hline 4 & Uang eletronik & 0 & $0 \%$ \\
\hline 5 & Lainnya ..... & 0 & $0 \%$ \\
\hline \multicolumn{2}{|c|}{ Total } & 47 & $100 \%$ \\
\hline
\end{tabular}

Sumber : Hasil Penelitian (2019)

Pengemudi transportasi konvensional di Kelurahan Ubud secara intens menawarkan jasa mereka pada siang hari. Sedangkan pada pagi dan malam hari, penawaran yang dilakukan tidak begitu intens. Hal ini tidak terlepas dari tingkat permintaan wisatawan dimana semakin tinggi tingkat permintaan maka akan semakin rendah tingkat penawaran. Begitu pula halnya pada bulan Juni sampai Agustus yang merupakan puncak tertinggi kunjungan wisatawan, khususnya wisatawan mancangera. Penawaran akan layanan jasa transportasi juga dipengaruhi oleh ketersediaan pengemudi. Penawaran akan semakin rendah apabila ketersediaan pengemudi sedikit, seperti pada saat adanya upacara adat maupun keagamaan yang harus dijalankan oleh sejumlah pengemudi. Meski demikian, ketersediaan pengemudi dapat digantikan oleh pengemudi lain dari luar Kelurahan Ubud maupun dengan penerapan sistem pembagian tugas (shift). Penawaran pun dilakukan tak terlepas dari kegiatan negosisasi dengan wisatawan. Sebelum bersepakat dengan wisatawan, harga yang ditawarkan harus disesuaikan terlebih dahulu dengan ketentuan harga pasar yang telah ditetapkan oleh sesama pengemudi.

\subsection{Eksistensi Jasa Transportasi \\ Konvensional di Kelurahan Ubud pada Era Revolusi 4.0}

Kehadiran layanan transportasi online merupakan salah satu inovasi produk di bidang transportasi yang dihasilkan pada era revolusi industri 4.0 untuk memenuhi kebutuhan 
konsumen yang semakin dinamis. Menurut Anindhita, dkk (2016), transportasi online merupakan inovasi dalam penerapan penggabungan bisnis penyedia jasa transportasi dengan teknologi komunikasi yang berbasis data internet (dalam Ramadhan, dkk: 2018). Transportasi online dianggap efisien bagi para konsumen karena menawarkan kemudahan dalam proses pemesanan yang dapat dilakukan dengan ujung jari saja. Selain itu, layanan yang ditawarkan pun memberikan keamanan dan kenyamanan bagi para konsumen karena mereka dapat melihat dan memilih driver melalui rating pada aplikasi. Dengan dukungan teknologi, pengguna layanan transportasi online juga dapat memastikan waktu perjalanan mereka dan memberikan penilaian kepada pengemudi. Hal yang tidak kalah penting adalah harga yang ditawarkan sangat terjangkau ditambah pula dengan sejumlah diskon yang kerap diberikan.

Meskipun demikian, kehadiran transportasi online ini tidak terlepas dari sejumlah problematika yang sampai saat ini masih belum menemukan titik terang. Hampir di seluruh wilayah Indonesia maupun beberapa negara maju, kehadiran transportasi online ini mendapat kecaman dari oknum transportasi konvensional, utamanya pihak penyedia layanan transportasi umum karena dianggap telah merusak sistem. Di era revolusi industri 4.0 yang sudah sangat dengan dengan teknologi ini, para pengguna layanan transportasi konvensional/umum seketika berpindah ke transportasi online. Hal ini kemudian memancing terjadinya sejumlah aksi penolakan dan demonstrasi yang tidak jarang berujung anarkis. Menyikapi permasalahan tersebut, beberapa pakar hukum menyebutkan bahwa hal itu bukan dikarenakan kesalahan dari salah satu pihak. Lagi-lagi, pemerintah dituding menjadi penyebab dari semua kekacauan ini karena dianggap tidak mampu dalam merumuskan sebuah kebijakan yang secara khusus mengatur persaingan bisnis transportasi di era digital.

Permasalahan ini pun turut terjadi di Provinsi Bali sebagai destinasi wisata kelas dunia. Kendati keberadaan transportasi umum di Pulau Seribu Pura ini sangat minim namun kehadiran transportasi online tetap menjadi permasalahan serius, khususnya bagi masyarakat lokal yang bekerja sebagai pengemudi taksi konvensional di Kelurahan Ubud. Konteks permasalahan di Bali dan daerah jelas sangat berbeda. Hal ini dikarenakan target pasar layanan transportasi di Bali adalah wisatawan, baik domestik maupun mancanegara sementara di daerah lain konsumen utamanya adalah masyarakat umum. Wisatawan melakukan perjalanan wisata karena mereka memiliki waktu luang dan disposable income yang sengaja disisihkan untuk liburan. Sehingga, mereka telah dianggap siap secara finansial untuk melakukan suatu perjalanan, termasuk didalamnya untuk membayar layanan transportasi. Berbeda dengan masyarakat umum yang menggunakan layanan transportasi bukan untuk berlibur melainkan untuk mendukung aktivitas ekonomi mereka, seperti bekerja. Inilah yang kemudian menjadi representasi argumen masyarakat lokal sebagai penyedia jasa transportasi konvensional di Kelurahan Ubud yang menyesali kehadiran transportasi online di daerah mereka.

Transportasi online mulai merambah di Kelurahan Ubud pada tahun 2014 lalu oleh perusahan UBER yang kemudian disusul GRAB pada tahun 2015 dan Go-Car pada tahun 2017. Kehadiran perusahaan penyedia jasa transportasi online ini tidak dapat dikatakan sebagai bentuk persaingan tidak sehat karena tidak sesuai dengan kriteria yang telah diatur berdasarkan Undang-Undang Nomor 5 Tahun 1999 tentang Larangan Praktik Monopoli dan Persaingan Usaha Tidak Sehat. Kehadiran jasa transportasi online ini justru berupaya untuk memberi alternatif pelayanan yang lebih praktis dan mudah bagi wisatawan dalam melakukan perjalanan. Namun demikian, pihak pengemudi jasa transportasi konvensional di Kelurahan Ubud sangat menyayangkan ketetapan harga yang ditawarkan oleh pihak perusahaan jasa transportasi online kepada wisatawan mancangera. Harga tersebut dianggap terlalu murah bagi wisatawan mancanegara yang notabennya memiliki nilai mata uang jauh lebih tinggi daripada rupiah.

Penawaran harga yang jauh lebih murah oleh pihak transportasi online membawa pengaruh yang sangat besar bagi masyarakat lokal di Kelurahan Ubud. Harga tersebut telah merusak harga pasaran yang telah disepakati oleh masing-masing organisasi di Kelurahan Ubud. Sehingga, banyak pengemudi yang mau tidak mau harus menurunkan harga dari ketentuan sebelumnya. Sebagai contoh, pada tahun 2013, biaya perjalanan yang dikenakan untuk layanan transportasi dari Kelurahan Ubud ke Bandara Ngurah Rai sebesar Rp 450.000,00 Rp 500.000,00 namun dewasa ini harga tersebut terpaksa diturunkan menjadi $\mathrm{Rp} 250.000,00-\mathrm{Rp}$ $300.000,00$ agar pengemudi mendapatkan pelanggan dan pendapatan. Harus diakui bahwa harga yang ditawarkan oleh pengemudi lokal tergolong mahal karena sistem pelayanan mereka adalah one-way atau sistem drop off saja. Tidak hanya di Kelurahan Ubud, sistem ini juga berlaku hampir di semua wilayah yang menawarkan layanan transportasi konvensional karena setiap pengemudi tidak diperkenankan 
untuk mengangkut penumpang dari wilayah orang lain.

Dengan masuknya kehadiran transportasi online, pendapatan pengemudi lokal pun mengalami penurunan yang cukup drastis. Jika dulu mereka dapat mengangkut penumpang rata-rata empat sampai lima orang, sekarang mereka hanya mendapat dua sampai tiga penumpang saja. Beberapa pengemudi bahkan sering tidak mendapatkan penumpang dalam sehari. Kondisi ini dikhawatirkan akan mengancam keberlanjutan pekerjaan mereka dan generasinya di masa mendatang. Masyarakat khawatir jika kelak lapangan pekerjaan yang menjadi hak milik mereka akan dikuasi oleh kaum kapitalis, berkaca dari sejumlah usaha pariwisata lain di Kelurahan Ubud yang dimiliki oleh orang luar.

Lebih dari itu, kehadiran transportasi online ini juga telah merusak kepercayaan wisatawan terhadap pengemudi lokal. Mereka kerap menuduh pengemudi lokal sebagai penipu karena menawarkan harga yang sangat mahal. Argumen ini pun baru mencuat setelah hadirnya transportasi online dimana wisatawan mengkomparasi harga yang ditawarkan dengan harga transportasi konvensional. Sentimen wisatawan ini dianggap telah merusak citra pariwisata Kelurahan Ubud yang selama ini telah susah payah dibangun oleh masyarakat lokal melalui pelayanan terbaik mereka, termasuk didalamnya pengemudi lokal.

Menyikapi kehadiran transportasi online yang semakin meresahkan pengemudi lokal karena dianggap sebagai ancaman terhadap eksistensi mereka, akhirnya didirikanlah sebuah organisasi khusus di tahun 2017, yaitu Bali Agung Ubud (BAU). Organisasi ini berada di bawah naungan Pecalang atau organisasi keamanan lokal yang dikelola oleh Desa Adat dimana masyarakat Bali jauh lebih hormat dan taat kepada Pecalang daripada pihak kepolisian karena sanksi hukum adat dianggap jauh lebih berat daripada hukum formal. Organisasi ini dibentuk sebagai back-up pengemudi lokal dalam mempertahankan eksistensinya. BAU membuat suatu aturan yang melarang transportasi online untuk mengangkut penumpang dari dalam Kelurahan Ubud namum memperkenankan mereka untuk drop off penumpang. Hampir di sepanjang ruas jalan di Kelurahan Ubud terdapat spanduk atau plang larangan bagi transportasi online. Jika transportasi online melanggar hal tersebut maka pihak Pecalang akan memberikan teguran bagi mereka dimana penumpang akan diturunkan dan dialihkan kepada pengemudi lokal. Apabila pelanggaran tersebut dilakukan lebih dari satu kali maka pengemudi online akan dikenakan sanksi denda yang akan disumbangkan kepada desa adat. Dengan adanya organisasi ini, eksistensi transportasi konvensional di Kelurahan Ubud masih tetap bertahan meskipun terkesan sedikit memaksa.

Masuknya transportasi online di Kelurahan Ubud sebenarnya tidak menjadi sebuah ancaman bagi pengemudi lokal jika harga yang ditawarkan disesuaikan dengan harga pasaran. Pengemudi lokal menerima adanya persaingan dalam bentuk perbedaan metode penawaran jasa namun menolak keras adanya perbedaan harga yang sangat mencolok. Perlu diketahui bahwa pengemudi lokal di Kelurahan Ubud, baik masyarakat lokal maupun pengemudi dari luar desa setiap bulannya membayar iuran sebesar Rp 300.000,00 yang akan disumbangkan kepada desa adat untuk kepentingan pembangunan infrastruktur dan pembiayaan upacara adat/keagamaan. Hal ini berbeda dengan oknum transportasi online yang sama sekali tidak memberikan kontribusi bagi desa adat tetapi justru menjadi ancaman bagi kesejahteraan masyarakat lokal. Sehingga, pengemudi lokal berharap jika transportasi online masuk ke Kelurahan Ubud, mereka juga harus turut berkontribusi bagi desa adat.

Penolakan terhadap transportasi online juga didukug dengan ketidak-nyamanan pengemudi lokal terhadap para wisatawan yang menyewa motor dari luar Keluarahan Ubud. Pengemudi lokal sering mempertanyakan legalitas dari perusahaan penyedia jasa rental tersebut, apakah mereka turut berkontribusi dengan membayar pajak kepada negara maupun memberikan sumbangsih kepada pihak desa. Disamping itu, peningkatan volume kendaran di Kelurahan Ubud juga merupakan penyebab utama kemacetan di daerah ini karena para wisatawan biasanya parkir di kantong-kantong jalan yang tidak diperuntukkan untuk lahan parkir.

Berdasarkan hasil wawancara dengan sejumlah pengemudi lokal, Pemerintah Provinsi Bali sebenarnya sudah pernah menawarkan pembuatan aplikasi online bagi mereka untuk mengatasi peliknya permasalahan di Kelurahan Ubud. Namun, pengemudi lokal menolak gagasan tersebut secara mentah-mentah karena mereka lebih menyukai adanya interaksi secara langsung dengan wisatawan. Bahkan untuk mengarah ke sistem online pun pengemudi lokal belum memiliki niatan sama sekali. Kualitas pelayanan inilah yang selalu menjadi tameng pengemudi lokal untuk menolak serangan transportasi online di Kelurahan Ubud. Mereka meyakini bahwa pelayanan yang diberikan selama ini jauh lebih baik dari pelayanan para pengemudi transportasi online karena mereka juga merangkap sebagai pemandu wisata. Semua 
pengemudi lokal diharuskan untuk memiliki kemampuan berkomunikasi sekurang-kurangnya dalam Bahasa Inggris, beberapa dari mereka bahkan menguasai lebih dari dua bahasa. Sementara kebanyakan dari pengemudi online sama sekali tidak memiliki kemampuan komunikasi dalam bahasa asing sehingga tidak connect dengan para wisatawan dan tidak mampu memberikan pelayanan yang terbaik. Hal ini ditakutkan akan membuat citra pariwisata Ubud menjadi jelek.

Para pengemudi lokal ini pun selalu berupaya untuk mempertahankan keajegan (keaslian) Bali ketika sedang mengantarkan wisatawan. Mereka selalu memberikan informasi dan edukasi kepada wisatawan mengenai nilai budaya, norma, maupun larangan di suatu daya tarik wisata. Misalnya, mengingatkan para wisatawan wanita yang sedang menstruasi agar tidak memasuki kawasan suci seperti pura. Tentunya hal ini tidak akan disampaikan oleh pengemudi transportasi online yang bertugas hanya untuk mengantarkan wisatawan bukan untuk melayani mereka. Keunggulan lain yang disampaikan oleh para pengemudi lokal adalah fleksibilitas mereka dalam melayani wisatawan kemana dan kapanpun. Berbeda dengan transportasi online yang hanya terpaku pada aplikasi. Pengemudi lokal berpendapat bahwa harga yang ditawarkarkan mahal bukan karena menjual proses perpindahannya tetapi layanan jasa yang diberikan.

Sejumlah fakta diatas mencerminkan bahwa selama ini praktik kepariwisataan di Kelurahan Ubud adalah berbasis masyarakat. Hal ini tidak terlepas dari peran masyarakat dalam mengelola dan mengendalikan aktivitas pariwisata di desa mereka, dalam hal ini desa adat. Peran masyarakat sangat kuat dalam mempertahankan sistem yang sudah ada sejak lama dan menolak adanya inovasi dari pihak asing. Hasil yang mereka peroleh dari sektor pariwisata pun akan disumbangkan untuk kepentingan sosial budaya masyarakat, seperti upacara adat dan keagamaan.

Meskipun demikian, hal tersebut tidak menjamin adanya kesamaan persepsi antara pengemudi lokal dengan wisatawan yang menggunakan jasa transportasi konvensional di Kelurahan Ubud. Untuk itu, diperlukan adanya analisis kepuasan wisatawan terhadap kualitas pelayanan transportasi konvesional dengan dua indikator, yaitu tingkat harga dan kualitas pelayanan. Kedua indikator tersebut merupakan faktor terpenting yang memengaruhi tingkat permintaan. Berikut adalah hasil analisis yang telah dilakukan :
Tabel 4.9 Tingkat Kepuasan Wisatawan terhadap Kualitas Pelayanan Jasa Transportasi Konvensional di Kelurahan Ubud

\begin{tabular}{|c|c|c|c|c|}
\hline \multirow[t]{2}{*}{ No } & \multirow{2}{*}{ Indikator } & \multicolumn{2}{|c|}{ Nilai Rata-Rata } & \multirow{2}{*}{$\begin{array}{c}\text { Tingkat } \\
\text { Kepuasan } \\
\text { Wisatawan }\end{array}$} \\
\hline & & $\mathbf{X}$ & $\mathbf{Y}$ & \\
\hline 1 & $\begin{array}{l}\text { Harga yang ditawarkan } \\
\text { terjangkau }\end{array}$ & 3,26 & 3,81 & $\begin{array}{l}86 \% \\
\text { (Puas) }\end{array}$ \\
\hline 2 & $\begin{array}{l}\text { Kualitas pelayanan sesuai } \\
\text { dengan harga yang telah } \\
\text { dibayar }\end{array}$ & 3,23 & 3,89 & $\begin{array}{c}83 \% \\
\text { (Puas) }\end{array}$ \\
\hline 3 & $\begin{array}{l}\text { Pengemudi memiliki } \\
\text { hospitalitas yang baik }\end{array}$ & 3,23 & 3,83 & $\begin{array}{l}84 \% \\
\text { (Puas) }\end{array}$ \\
\hline 4 & $\begin{array}{l}\text { Mekanisme pemesanan } \\
\text { mudah dan praktis }\end{array}$ & 2,98 & 3,94 & $\begin{array}{c}76 \% \\
\text { (Cukup Puas) }\end{array}$ \\
\hline 5 & $\begin{array}{l}\text { Sistem pembayaran mudah } \\
\text { dan sesuai dengan } \\
\text { kesepakatan sebelumnya }\end{array}$ & 3,15 & 3,91 & $\begin{array}{l}80 \% \\
\text { (Puas) }\end{array}$ \\
\hline & Total & 15,84 & 19,38 & $\begin{array}{l}\mathbf{8 2} \% \\
\text { (Puas) }\end{array}$ \\
\hline
\end{tabular}

Sumber : Hasil Penelitian (2019)

Berdasarkan tabel 4.9, diketahui bahwa secara keseluruhan wisatawan merasa puas (82\%) dengan tingkat harga dan pelayanan kualitas yang diberikan oleh penyedia jasa transportasi konvensioal. Wisatawan merasa puas (86\%) dengan harga yang ditawarkan karena dianggap terjangkau jika dibandingkan dengan harga pada negara asal mereka. Mereka juga puas dengan kualitas pelayanan (83\%) dan hospitalitas (84\%) para pengemudi. Pada indikator mekanisme pelayanan yang mudah dan praktis, wisatawan merasa cukup puas $(76 \%)$ karena adanya perubahan gaya hidup yang serba instan di era revolusi industri 4.0, khususnya bagi wisatawan milenial. Pada indikator sistem pembayaran yang mudah dan sesuai dengan kesepakatan sebelumnya, wisatawan pun sudah merasa puas (82\%). Berikut ini adalah analisis Importance Performance Analysis (IPA) untuk memperoleh grafik yang dapat dijadikan sebagai acuan bagi penyedia jasa transportasi konvensional dalam mempertahankan eksistensinya :

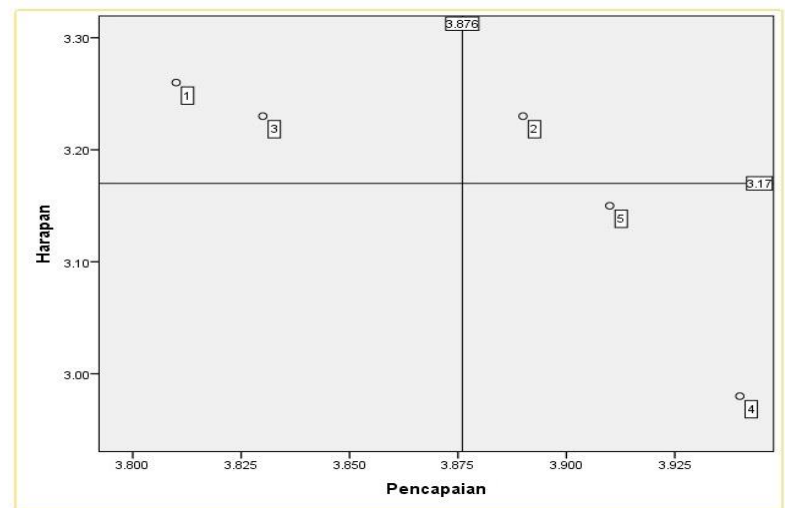

Gambar 4.1 Grafik Importance Performance Analysis Sumber : Hasil Penelitian (2019) 
Tabel 4.10 Analisis Kuadran Harapan dan Pencapaian

\begin{tabular}{|c|l|}
\hline Kuadran & \multicolumn{1}{|c|}{ Indikator } \\
\hline $\begin{array}{c}\text { I } \\
\text { (Prioritas Utama) }\end{array}$ & $\begin{array}{l}\text { (1) Harga yang ditawarkan terjangkau } \\
\text { (3) Pengemudi memiliki hospitalitas yang baik }\end{array}$ \\
\hline $\begin{array}{c}\text { II } \\
\text { (Pertahankan Prestasi) }\end{array}$ & $\begin{array}{l}\text { (2) Kualitas pelayanan sesuai dengan harga yang } \\
\text { dibayarkan }\end{array}$ \\
\hline $\begin{array}{c}\text { III } \\
\text { (Prioritas Rendah) }\end{array}$ & Tidakada \\
\hline $\begin{array}{c}\text { IV } \\
\text { (Berlebihan) }\end{array}$ & $\begin{array}{l}\text { (5) Sistem pembayaranyang mudah dan praktis } \\
\text { (4) Mekanisme pemesananyang mudah dan praktis }\end{array}$ \\
\hline
\end{tabular}

Sumber : Hasil Penelitian (2019)

Berdasarkan tabel 4.10, dapat dilihat bahwa harga yang terjangkau dan hospitalitas pengemudi merupakan faktor yang sangat penting terhadap kepuasan wisatawan namun belum mampu dipenuhi oleh pengemudi jasa transportasi konvensional dengan baik sehingga perlu diperbaiki. Kemudian, indikator kualitas pelayanan sesuai dengan harga yang ditawarkan dianggap penting dan telah dipenuhi dengan baik sehingga harus dipertahankan. Sementara pada indikator sistem pembayaran dan mekanisme pemesanan yang mudah dan praktis dinilai kurang penting namun memiliki tingkat pelaksanaan kinerja yang tinggi. Sehingga, pihak pengemudi transportasi konvensional baiknya mengurangi fokus pada kedua indikator ini dan mengalokasikan perhatian pada indikator lain, seperti harga, hospitalitas dan kualitas pelayanan.

Dari penjelasan diatas dapat dilihat bahwa pengemudi konvensional yang selama ini menganggap kualitas pelayanan mereka baik ternyata masih dinilai kurang maksimal oleh wisatawan. Hal ini dikarenakan cara mereka dalam menawarkan jasa transportasi di pinggir jalan dianggap cukup mengganggu dan justru tidak mencerminkan adanya hospitalitas yang baik. Harus diakui bahwa pengemudi lokal memang cenderung memaksa dalam menawarkan jasa meskipun selama di perjalanan mereka memberikan kualitas pelayanan yang baik. Penjelasan diatas juga menunjukkan bahwa kemudahan dalam proses pemesanan jasa transportasi di Kelurahan Ubud bukan merupakan hal penting yang bertolak dari konsep revolusi industi 4.0 pada umumnya. Hal ini sekaligus mencerminkan bahwa ketersediaan jasa transportasi konvensional di Ubud sudah memadai dan mudah didapatkan.

Wisatawan menilai bahwa harga layanan yang ditawarkan relatif mahal berbeda dengan persepsi pengemudi lokal yang menganggap bahwa hal tersebut adalah wajar karena adanya perbedaan nilai mata uang. Namun, wisatawan yang berkunjung ke Kelurahan Ubud tampaknya mengalami pergeseran yang cukup mencolok.
Jika dahulu pengunjung mayoritas adalah wisatawan senior yang memiliki disposable income yang tinggi berbeda dengan kondisi saat ini yang didominasi oleh wisatawan milenial dengan budget terbatas. Sehingga, mau tidak mau pengemudi lokal harus menurunkan tarif harga dengan menekan biaya operasional perjalanan melalui perubahan sistem layanan one-way.

Untuk mengatasi hal tersebut, pemerintah daerah baiknya membuat sebuah regulasi khusus untuk mengatur tarif harga layanan transportasi di Provinsi Bali dan Kabupaten Gianyar. Dalam Peraturan Menteri Perhubungan Nomor 118 Tahun 2018 disebutkan bahwa angkutan sewa khusus merupakan pelayanan angkutan dari pintu ke pintu dengan pengemudi, memiliki wilayah operasi dalam wilayah perkotaan, dari dan ke bandar udara, pelabuhan, atau simpul transportasi lainnya serta pemesanan menggunakan aplikasi berbasis teknologi informasi, dengan besaran tarif tercantum dalam aplikasi. Transportasi online dalam hal ini merupakan bagian dari angkutan sewa khusus yang operasionalnya hanya dilakukan pada kawasan perkotaan saja. Sementara Kelurahan Ubud merupakan kawasan perdesaan yang memiliki karakteristik kota karena adanya aktivitas kepariwisataan. Sehingga, Pemerintah Provinsi Bali dan Pemerintah Kabupaten Gianyar baiknya membuat sebuah peraturan yang secara tegas melarang adanya operasional trannsportasi online di Kelurahan Ubud yang bukan merupakan kawasan perkotaan seperti halnya yang telah ditetapkan melalui peraturan desa adat.

Hal ini sangat diperlukan mengingat persepsi wisatawan atas harga transportasi konvensional yang mahal terkonstruksi melalui proses komparasi penawaran harga dengan layanan transportasi online. Pemerintah daerah baiknya berkoordinasi dengan pihak penyedia layanan jasa transportasi online agar menutup akses secara penuh di Kelurahan Ubud sebagaimana sesuai dengan peraturan formal maupun adat yang berlaku. Kewenangan ini didukung oleh Permenhub 118/2018 Pasal 7 Ayat 2A yang menjelaskan bahwa penetapan wilayah operasi angkutan sewa yang melampaui satu daerah kabupaten/kota dalam satu provinsi ditentukan oleh Gubernur.

Untuk menentukan memberikan akses kepada pihak transportasi online, Gubernur juga perlu melakukan analisis terhadap perkiraan kebutuhan angkutan sewa dengan sejumlah stakeholder. Di wilayah Kelurahan Ubud, kebutuhan akan transportasi online sudah jelas tidak diperlukan karena adanya layanan transportasi konvensional yang over supply. Selain itu, kehadiran transportasi online juga secara gamblang ditolak oleh masyarakat 
Kelurahan Ubud karena mereka ingin mempertahankan nilai dan mencerminkan autensitas kearifan lokal yang mulai tergerus arus modernisasi.

Kebijakan ini juga akan memberikan variasi terhadap pelayanan jasa transportasi di Provinsi Bali yang sekaligus menjadi pembeda dengan daerah lain. Selain itu, hal ini juga akan mendukung eksistensi jasa transportasi konvensional tetap bertahan dimana paradigma pengembangan kepariwisataan di Kelurahan Ubud adalah berbasis partisipasi masyarakat. Sehingga, terjadi sinergitas antara sektor pariwisata dengan kehidupan sosial masyarakat tanpa adanya intervensi pihak asing yang akan memicu timbulnya konflik.

\section{SIMPULAN}

Berdasarkan hasil penelitian dapat disimpulkan bahwa tingkat permintaan atas layanan jasa transportas konvensional di Kelurahan Ubud, Bali sangat dipengaruhi oleh faktor harga, jarak tempuh dan lama penggunaan yang saling berkaitan satu sama lain. Permintaan dengan rentang tarif Rp 0 - 100.000,00 dan lama penggunaan 0-1 jam menjadi yang tertinggi dengan persentase $38 \%$ dan $32 \%$. Tingkat harga dan lama penggunaan ini sangat dipengaruhi oleh jarak tempuh yang hendak dicapai wisatawan. Permintaan atas layanan jasa transportasi konvensional ini cenderung stabil baik pada hari kerja maupun hari libur namun mengalami peningkatan yang cukup signifikan pada saat high season, yaitu bulan Juni sampai Agustus. Penawaran layanan jasa transportasi konvensional dilakukan dengan lima cara, yaitu pengemudi menawarkan secara langsung kepada wisatawan, melalui loket khusus milik desa adat, bekerjasama dengan sejumlah akomodasi, pemanfaatan media sosial maupun melalui rekomendasi dari wisatawan sebelumnya. Penawaran secara langsung yang dilakukan oleh para pengemudi lokal menjadi sumber informasi utama bagi wisatawan, yaitu sebesar $55 \%$ sekaligus mendominasi $75 \%$ mekanisme pemesanan jasa transportasi konvensional yang dilakukan di Kelurahan Ubud. Penawaran tertinggi dilakukan pada siang hari karena rendahnya permintaan dari wisatawan.

Kehadiran jasa transportasi online $\mathrm{di}$ Kelurahan Ubud menjadi ancaman terhadap eksistensi jasa transportasi konvensional karena berdampak terhadap penurunan permintaan wisatawan. Untuk mengatasi hal tersebut, masyarakat kemudian membentuk organisasi Bali Agung Ubud (BAU) yang dikelola oleh desa adat dan melarang transportasi online beroperasi di Kelurahan Ubud. Hasil analisis Importance Performance Analysis menunjukkan bahwa harga yang terjangkau dan hospitalias pengemudi merupakan aspek yang sangat penting bagi wisatawan namun masih belum terpenuhi sehingga perlu ditingkatkan. Kesesuaian harga dengan pelayanan yang diberikan oleh pengemudi lokal patut dipertahankan karena dinilai penting oleh wisatawan dan telah dilakukan dengan baik sejauh ini. Sementara itu, sistem pembayaran maupun mekanisme pemesanan yang mudah dan praktis dianggap tidak begitu penting bagi wisatawan. Hal ini bertolakbelakang dengan konsep revolusi industri 4.0 yang mengutamakan kemudahan pelayanan sekaligus merefleksikan bahwa ketersediaan layanan tansportasi konvensional di Kelurahan Ubud sudah memadai dan mudah didapatkan.

SARAN

Adapun saran yang diberikan dalam penelitian ini adalah sebagai berikut :

1. Pengemudi lokal di Kelurahan Ubud sebaiknya meningkatkan hospitalitas, utamanya ketika menawarkan jasa kepada para wisatawan dan perlu untuk mempertimbangkan kembali tarif harga yang diberikan;

2. Pemerintah Provinsi Bali maupun Pemerintah Kabupaten Gianyar sebaiknya mengeluarkan regulasi yang mengatur zonasi terkait dengan wilayah operasional transportasi online di Kelurahan Ubud yang menjadi penyebab utama penurunan permintaan layanan transportasi konvensional;

3. Pihak penyedia dan pengemudi transportasi online patutnya mengikuti peraturan desa adat yang berlaku, khususnya terkait dengan pengangkutan penumpang dari dalam Kelurahan Ubud.

\section{DAFTAR PUSTAKA}

Adha, Muhammad Rizka Nur. 2018. Analisis Dampak Adanya Transportasi Online di Wilayah Perkotaan Terhadap Moda Transportasi Umum : Sudi Kasus Pengguna Jasa Transportasi Umum di Kota Medan. Skripsi. Medan: Universitas Muhammadiyah Sumatera Utara.

Adiprana, I Putu Gatot, I.G.A Oka Mahagangga. 2013. Dinamika Perkembangan Pariwisata di Desa Pakraman Ubud. Jurnal Destinasi Pariwisata, Vol. 1 (1), Hal. $34-43$

Andriyansah. 2015. Manajemen Transportasi dalam Kajian dan Teori. Jakarta Pusat : Fakultas Ilmu Sosial dan Politik Universitas Prof. Moestopo Beragama. 
Angraini, Putri Ayu. 2018. Studi Komparatif Pelayanan Taksi Online dan Taksi Konvensional Terhadap Kepuasan Pelanggan dalam Perspektif Ekonomi Islam. Skripsi. Lampung : Universitas Islam Negeri Raden Intan Lampung.

Anonim. 2019. 2018, Gianyar Raup 2,7 Juta Wisatawan. 2019 Bagaimana?

https://bali-

travelnews.com/2019/01/07/2018-

gianyar-raup-27-juta-wisatawan-2019-

bagaimana/

(Diakses pada Tanggal 21 September 2019, Pukul 13.47 WITA)

Arida, I Nyoman Sukma. 2017. Ekowisata : Pengembangan, Partisipasi Lokal, dan Tantangan Ekowisata. Denpasar : Cakra Press.

Astajaya, Manik. 2018. 2017, Kunjungan Wisatawan ke Kabupaten Gianyar Capai 3,8 Juta. http://www.balipost.com/news/2018/04/ 19/43324/2017,Kunjungan-Wisatawan-keGianyar...html

(Diakses pada Tanggal 21 September 2019, Pukul 13.47 WITA)

Ayu, Dewi Aulya Atika, Suharyono, Wilopo. 2015. Peran Promosi Pariwisata Melalui Film dalam Meningkatkan Jumlah Kunjungan Wisatawan : Perbandingan antara Film "Eat Pray Love" dengan Film yang Berlatar Belakang Destinasi Wisata. Jurnal Administrasi Bisnis, Vol. 26 (1).

Azizah, Ayu, Popon Rabia Adawia. 2018. Analisis Perkembangan Industri Transportasi Online di Era Revolusi Disruptif : Studi Kasus PT Gojek Indonesia. Jurnal Humaniora Cakrawala, Vol. 18 (2), Hal. 149 - 156.

Bungin, Burhan. 2005. Metodologi Penelitian Kuantitatif : Komunikasi, Ekonomi, Kebijakan Publik serta Ilmu-Ilmu Sosial Lainnya. Jakarta : Penerbit Kencana.

Bungin, Burhan. 2007. Penelitian Kualitatif : Komunikasi, Ekonomi, Kebijakan Publik dan Ilmu Sosial Lainnya. Jakarta : Penerbit Kencana.

Creswell, Jhon W. 2012. Research Design : Qualitative, Quantitative, and Mixed Method Approaches. Edisi Ketiga. Diterjemahkan oleh : Achmad Fawaid. Yogyakarta : Pustaka Belajar.

Dewi, Ni Luh Putu Sukma. 2015. Faktor-Faktor yang Memengaruhi Perubahan Kawasan Pusat Kota Ubud yang Mencitrakan Ruang Tradisional Bali. Tugas Akhir. Surabaya : Institut Teknologi Sepuluh November (ITSN) Surabaya.

Hadi, Irfan Ariffianto. 2015. Eksistensi Komunitas Waroeng Keroncong di Kota Semarang.
Skripsi. Semarang : Universitas Negeri Semarang.

Idrus, Muhammad. 2009. Metode Penelitian Ilmu Sosial : Pendekatan Kualitatif dan Kuantitatif. Jakarta : Penerbit Erlangga.

Idrus, Syech. 2018. Perspektif Sumber Daya Manusia Pariwisata di Era Revolusi Industri 4.0. Prosiding Sintesa, Hal. $587 \quad-594$. Universitas Dhyana Pura Bali.

Irwandi, Endah R. Chotim. 2017. Analisis Konflik Antara Masyarakat, Pemerintah, dan Swasta: Studi Kasus di Dusun Sungai Samak, Desa Sungai Samak, Kecamatan Badau, Kabupaten Belitung. Jurnal JISPO, Vol. 7 (2), Hal. $24-42$.

Labola, Yostan Absalom. 2018. Konflik Sosial : Dipahami, Identifikasi Sumbernya dan Dikelola Kajian Literature.

https://www.researchgate.net/publication/ 322628213 Konflik Sosial Dipahami Identi fikasi Sumbernya dan Dikelola-

Kajian Literature

(Diakses pada tanggal 18 September 2019, Pukul 18.12 WITA)

Lazuardi, Adi 2019. 2019, Gianyar Targetkan Kunjungan Wisman 3 Juta Orang. https://bali.antaranews.com/berita/14107 7/2019-gianyar-targetkan-kunjunganwisman-3-juta-orang

(Diakses pada Tanggal 21 September 2019, Pukul 13.47 WITA)

Majid, Abdul. 2015. Eksistensi, Bentuk Penyajian dan Fungsi Kesenian Tradisional Orek-Orek di Kabupaten Rembang. Skripsi. Semarang : Universitas Negeri Semarang.

Maltais Pierre Oliver Bédard. 2017. Industry 4.0 : The New Industrial Revolution : Are Canadian Manufactures Ready ?. Kanada : Business Development Bank of Canada (BDC).

Meranti, Irwansyah. 2018. Kajian Humas Digital : Transformasi dan Kontribusi 4.0 pada Stratejik Kehumasan. Jurnal Teknologi Informasi dan Komunikasi, Vol. 7 (1), Hal. $27-36$.

Moleong, Lexy J. 2014. Metodologi Penelitian Kualitatif. Edisi Revisi. Jakarta : PT Remaja Rosdakarya.

Muhadjir, Noeng. 1996. Metodologi Penelitian Kualitatif. Edisi Ke-3. Yogyakarta : Penerbit Rake Sarasin.

Narrotama, Nararya. 2018. Pariwisata dan Digital Nomad di Ubud : Konversi Modal Budaya menjadi Modal Ekonomi. Prosiding Seminar Nasional dan Call for Paper Pariwisata dalam Pusaran Gelombang Revolusi Digital 4.0. Denpasar : Udayana University Press.

Ningsih, Ni Wayan Ariyoshi Sastra. 2017. Pengembangan Desa Pakraman Negari sebagai Daya Tarik Wisata di Kabupaten 
Gianyar. Skripsi. Denpasar : Universitas Udayana.

Norhidayah, Fauza. 2014. Konsep Teori Eksistensialisme.

https://www.kompasiana.com/fauzanurhid ayah02/54f7bfdfa33311bd208b4966/kons ep-teori-eksistensialisme

(Diakses pada Tanggal 21 September 2019, Pukul 15.47 WITA)

Nurjaya, I Wayan.2013. Daya Tarik dan Aktivitas Wisata yang Digemari Wisatawan Mancanegara di Kelurahan Ubud. Jurnal Sosial dan Humaniora, Vol. 3 (2), Hal. 175185.

Peraturan Menteri Perhubungan Republik Indonesia. 2018. Permenhub No. 118/2018 Tentang Penyelenggaraan Angkutan Sewa Khusus. Jakarta : Kementerian Perhubungan.

Peraturan Menteri Perhubungan Republik Indonesia. 2019. Permenhub No. 15/2010 Tentang Penyelenggaraan Angkutan Orang dengan Kendaraan Bermotor Umum dalam Trayek. Jakarta : Kementerian Perhubungan.

Pribadiono, Agus. 2016. Transportasi Online VS Transportasi Tradisional Non Online Persaingan Tidak Sehat Aspek Pemanfaatan Aplikasi oleh Penyelenggara Online. Jurnal Lex Jurnalica, Vol. 13 (2), Hal. 126 - 138.

Pramudya, Wisnu, I Nyoman Sukma Arida. 2016. Kelurahan Ubud di Ambang Kemacetan Total. Jurnal Destinasi Pariwisata, Vol. 4 (2), Hal. $72-81$.

Prasetyo, Banu, Umi Trisyati. 2018. Revolusi 4.0 dan Tantangan Perubahan Sosial. Disampaikan dalam SEMATEKSOS pada tanggal 13 September 2019 di Gedung Rektorat ITS, Surabaya.

Prasetyo, Hoedi, Wahyudi Sutopo. 2018. Industri 4.0: Telaah Klasifikasi Aspek dan Arah Perkembangan Riset. Jurnal Teknik Industri,Vol. 13 (1), Hal 17-26.

Prastowo, Andi. 2016. Metode Penelitian Kualitatif dalam Perspektif RancanganPenelitian. Yogyakarta : Ar-Ruzz Media.

Putri, Amelia Permata, Yusri Abdillah. 2019. Analisis Perkembangan Industri Pariwisata dan Perubahan Nilai Budaya pada Kelurahan Ubud Kabupaten Gianyar. Jurnal Administrasi Bisnis (JAB), Vol. 68 (1), Hal. 918.

Ramadhanu, Arizky Kautsar, Supriono Supriono. 2018. Analisis Persepsi Kemanfaatan, Kemudahan, Kualitas, dan Harga Transportasi Online sebagai Sarana Penunjang Aksesiilitas Wisatawan di Kota Malang. Jurnal Administrasi Bisnis, Vol. 60 (2), Hal. $64-73$.

Retnowati, Eriska Dwi. 2013. Eksistensi Kesenian Gejog Lesung Sentung Lestasi di Dusun Nangsi, Desa Srihardono, Pundong, Bantul.
Skripsi. Yogyakarta : Universitas Negeri Yogyakarta.

Riswanda, Andi. 2019. Dampak Keberadaan Transportasi Online Terhadap Pendapatan Transportasi Konvensional : Studi Kasus Penarik Becak di Banda Aceh. Skripsi. Banda Aceh : Universitas Islam Negeri Ar - Raniry.

Sari, Etty Tuntas.2003. Analisis Kualitas Jasa Pelayanan Terhadap Kepuasan Pasien Rawat Inap di RSUD Wonogiri. Tugas Akhir. Surakarta : Universitas Surakarta. Setijowarno, Djoko, Russ Bona Frazila. 2001. Pengantar Sistem Transportasi. Semarang : Universitas Katolik Soegijapranata.

Siwu, Hanly Fendy Djohar. 2018. Permintaan dan Penawaran Jasa Transportasi. Jurnal Pembangunan Ekonomi dan Keungan Daerah, Volume 19 (6), Hal. 1 - 8.

Subudi, Made, dkk. 2012. Peran Kepemimpinan Puri sebagai Agent of Change Budaya Masyarakat Desa Adat Ubud. Jurnal Aplikasi Manajemen, Vol. 10 (1), Hal. 188 - 198.

Sumaryanto.2010. Manajemen Konflik sebagai Salah Satu dalam Pemecahan Masalah. Disampaikan dalam acara OPPEK Dosen Universitas Negeri Yogyakarta di Yogyakarta.

Sumiati, Ni Made. 2017. Dinamika Persaingan Usaha Masyarakat Lokal di Daerah Tujuan Wisata : Studi Komparasi pada Padangtegal Kaja Transport dan Taksi Aplikasi di Desa Padangtegal, Kecamatan Ubud, Bali. Skripsi. Denpasar : Universitas Udayana.

Sunaryo, Bambang. 2013. Kebijakan Pembangunan Destinasi Pariwisata : Konsep dan Aplikasinya di Indonesia. Yogyakarta : Penerbit Gava Media.

Supratno. 2011. Pengukuran Tingkat Kepuasan Pelanggan untuk Menaikkan Pangsa Pasar. Edisi Keempat. Jakarta : PT Rineka Cipta.

Syafrino, Aprima. 2017. Efisiensi dan Dampak Ojek Online Terhadap Kesempatan Kerja dan Kesejahteraan. Skripsi. Bogor : Institut Pertanian Bogor.

Veal, AJ. 2006. Research Methods for Leisure and Tourism. England : Pearson Education Limited.

Walliman, Nicholas. 2006. Social Research Methods. London : SAGE Publications Ltd.

Yahya, Muhammad. 2018. Era Industri 4.0 : Tantangan dan Peluang Perkembangan Pendidikan Kejuruan Indonesia. Disampaikan dalam Sidang Terbuka Luar Biasa Senar Universitas Negeri Makassar. 